\title{
HIERARQUIA E ORDEM: ORGANIZAÇÃO DO CORPO SOCIAL PORTUGUÊS QUINHENTISTA EM DOIS ESPAÇOS DISTINTOS
}

\author{
HIERARCHY AND ORDER: ORGANIZATION OF THE \\ BODY PORTUGUESE FIVE HUNDRED IN TWO DIFFERENT \\ SPACES
}

\author{
Fábio Eduardo Cressoni*
}

\begin{abstract}
Resumo: Este artigo tem por objetivo analisar o modelo de organização social adotado pelo homem português quinhentista. Nesse sentido, do rei ao mais simples oficial mecânico, consideramos as concepções de hierarquia e ordem presentes nessa sociedade. Do entendimento político-teológico advindo da ideia de um Cosmos autorregulador da vida social, capaz de gerir a vida social, observamos as bases dessa disposição em duas dimensões do Império português: Portugal, sede desse mesmo império, e a América, uma de suas colônias. Pretende-se, pois, perceber as aproximações e distanciamentos no ser português entre estas diferentes espacialidades, a partir do estudo de uma série de práticas cotidianas que aproximam essas vivências do corpo social português.
\end{abstract}

Palavras-chave: Império português. Sociedade corporativa. Hierarquia e ordem.

\begin{abstract}
This article aims to analyze the social organization model adopted by the sixteenth-century Portuguese man. In this sense, to the king to the simplest mechanical officer, we consider the concepts of hierarchy and order present in this society. Politicaltheological understanding arising from the idea of a self-regulating cosmos of social life, able to manage the social life, we see the foundations of this provision in two dimensions of the Portuguese Empire, Portugal, home of that empire, and America, one of its colonies. It is intended, therefore, understand the similarities and differences between them being Portuguese in different spatiality from the study of a series of everyday practices that brig these experiences of the body politic portuguese.
\end{abstract}

Keywords: Portuguese Empire. Society corporate. Hierarchy and order.

* Doutorando no Programa de Pós-Graduação em História da Universidade Estadual Paulista Júlio de Mesquita Filho (UNESP) e professor na Fundação Hermínio Ometto (UNIARARAS). E-mail: cressoni@uniararas.br 


\section{INTRODUÇÃO}

A visão que regia a organização social portuguesa quinhentista estava inserida em um contexto mais amplo, definido pela presença de uma Ordem Cósmica. Essa ordem abrangia a tudo e a todos, devendo compreender todos os seres existentes na Terra. Tudo que possuísse ou que já havia tido vida haveria de se inserir na contemplação de um Cosmos, que era organizado por Deus.

A permanência de cada parte do Cosmos dependia, em última instância, da constante ligação com as demais partes existentes. Não poderia haver divisões. Entender-se como uma das peças dessa criação, era sentir-se, com efeito, como um membro indispensável para a composição desse conjunto.

Todos deveriam agir para a maior glória de Deus. A função de cada grupo social era importante para a manutenção da totalidade existente. A ação de cada parte não deveria ser praticada visando apenas atender a si própria. Os anseios e as obrigações de um indivíduo se constituíam em ações coletivas, no sentido de que a unidade de todos os seres existentes os estabelecia como uma obra divina, fruto da vontade de Deus.

Considerando essa perspectiva, tudo estava em permanente contato. $\mathrm{O}$ Cosmos tornava possível essa interatividade, desde que mantido o ordenamento de todas as coisas, conforme predeterminado por Deus:

O pensamento social e político medieval é dominado pela idéia de existência de uma ordem universal (cosmos), abrangendo os homens e as coisas, que orientava todas as criaturas para um objectivo último, que o pensamento cristão identificava com o próprio Criador. ${ }^{1}$

Era obrigação comum atuar conforme sua competência, fazendo de sua função não apenas uma finalidade específica e individual, mas uma colaboração a existência e manutenção dessa unidade. Assim exigia o reino e, portanto, assim ficavam os portugueses encarregados de viver.

Havia, pois, aquele que deveria exercer o governo sobre os demais, caso do rei. Os oficiais mecânicos acabavam por encarregar-se de trabalhar. A justiça era função do desembargador. O senhor de engenho encarregar-se-ia de garantir a produção de açúcar. Aos missionários cabia a disseminação do catolicismo nas colônias lusitanas.

Dessa forma, cada qual com sua competência, todos acabavam por exercer, em obrigação com os demais, suas funções nessa sociedade. Cada parte do todo, por ser considerada divina, tinha enorme importância na composição do reino. A unidade ocorria justamente pela possibilidade de cada membro, ao ser diferente dos demais, completar a função não exercida pelo restante das pessoas inseridas em outros grupos sociais: 
A unidade dos objectivos da criação não exigia que as funções de cada uma das partes do todo na consecução dos objectivos globais da Criação fossem idênticas às das outras. Pelo contrário, o pensamento medieval sempre se manteve firmemente agarrado à idéia de que cada parte do todo cooperava de forma diferente na realização do destino cósmico. ${ }^{2}$

Todos, nestas condições, deveriam colocar-se a serviço de Deus. E, como já destacamos anteriormente, esse pôr-se a serviço, atuando para a confirmação e expansão da obra divina, obedecia a certa hierarquia. Abaixo de Deus, surgiam os homens, entre eles o rei, figura de maior destaque por sua posição social no plano terreno. Sua elevada condição em comparação com todos os demais súditos fazia do monarca o principal expoente da presença católica entre os homens.

Todos deveriam colaborar pela edificação dessa realidade social. Todavia, as diferenças presentes entre os grupos eram sentidas, sendo suprimidas pela perspectiva de manutenção do ordenamento social de caráter divino, que contemplava a sociedade.

A ideia da pré-existência de um grupo social opressor disposto a explorar os demais, acompanhada da probabilidade de uma classe opor-se a outra tomando o seu lugar não cabe na análise desse contexto social. E enfatizamos essa impossibilidade pelo seu caráter anacrônico, uma vez que, com o surgimento de conflitos, poderia haver luta pela regulamentação do modelo tomado como correto pelo Estado português, mas jamais em busca de uma suposta igualdade.

Nobres ou oficiais mecânicos, padres experientes ou seminaristas novos, todos se viam inseridos na mesma cultura. Vale, então, ressaltar que o sentido de pessoa enquanto ente individual não se faz presente aqui. Prevalecendo a noção de Cosmos, todos deveriam integrar-se a esta unidade:

[...] categorias psicológicas expressivas, pois "eu" e "tu" não correspondem a individualidades subjetivadas ou dotadas de direitos humanos na livre concorrência do mercado de bens culturais. Ou seja: "eu" e "tu" são representações obtidas por meio de aplicação de preceitos de uma racionalidade nãopsicológica e não-expressiva, uma racionalidade mimética, típica de esquemas coletivos e anônimos da sociedade de Corte portuguesa do século XVII transplantada para o trópico. ${ }^{3}$

A ideia de unidade aqui presente não se define apenas como o pertencer a uma determinada comunidade por ter nascido ou ter vivido na mesma. Um dos traços que perpassavam por todos os portugueses nesse período, consolidando 
essa ideia de unidade, era justamente a religiosidade. Era esse o sentimento de unidade que estabelecia a identidade portuguesa.

\section{O TEXTO EM SEU CONTEXTO: RELIGIOSIDADE, IDENTIDADE E CORPO SOCIAL}

Com efeito, o conceito de identidade nada tem a ver com a ideia de nação. A sociedade portuguesa do Antigo Regime possuía um sentido diferente. Entendemos que "pensar o tema da identidade portuguesa na época moderna, em termos de identidade 'nacional' remete implícita e anacronicamente para o conceito contemporâneo de nação". ${ }^{4}$ Os conceitos de identidade étnica, território e unidade política que concebem a ideia contemporânea de nação, acabam por excluir outras possibilidades de interpretação. ${ }^{5}$

Podemos pensar que a sociedade portuguesa quinhentista organizavase "a partir de certas crenças ou princípios", sendo que esse modo de viver expressava uma unidade. Nesse sentido, Mattoso é categórico ao afirmar que, "se procuramos saber qual é este sistema de crenças e de princípios que constitui o ponto de referência dos europeus, temos de reconhecer que é fundamentalmente o Cristianismo".?

Ao pensarmos nos aspectos que determinavam a realidade portuguesa quinhentista, faz-se necessário reportamo-nos novamente à ideia de ordem, inserindo-a nas circunstâncias que possibilitavam o viver entre os portugueses. Ordem, na sociedade que estamos a observar, subentende a existência de uma unidade.

Sem restrições, todos os seres deveriam fazer parte de um grande tecido social, elaborado por Deus. A este ordenamento liga-se a ideia de hierarquia. O organograma social desempenhado nessa sociedade não se efetivava para dividir, no sentido de obrigatoriamente determinar as posições de cada um, conforme a sujeição do mais fraco para com o mais forte. A divisão visava justamente garantir o contrário, isto é, a manutenção do corpo social. ${ }^{8}$

Cada ente fazia parte de um grupo. Uns viviam nobremente, administrando a Coroa ao lado do rei. Conselheiros, governadores, capitães, ouvidores e vereadores tratavam das questões cotidianas a luz da concepção régia. Fidalgos administravam terras no reino, enquanto capitães donatários cediam sesmarias na América aos homens que vinham da Península dispostos a empreenderem esforços na produção de açúcar.

Fosse a Portugal ou do outro lado do Atlântico, oficiais desempenhavam suas respectivas funções. Sapateiros, barbeiros, ferreiros, carpinteiros e tantos outros colaboravam, através de seus ofícios, com o desenvolvimento dessa realidade. $\mathrm{O}$ mesmo pode-se dizer dos clérigos. Competia a estes últimos zelarem pela cristandade, além de buscar a conversão daqueles que não conheciam e, portanto, não podiam crer na existência e obra divina do Criador. 
Todos, sem exceção, deveriam possuir o mesmo entendimento quanto ao orbe católico. No entanto, os missionários jesuítas, como membros letrados dessa sociedade e participantes da igreja enquanto instituição ligada diretamente à expansão do Império português eram os principais propagadores dessa racionalidade, fazendo, pois, da religiosidade um elemento presente na unificação do corpo social quinhentista português.

\section{ORDEM E HIERARQUIA NO CORPO SOCIAL QUINHENTISTA}

Todos deveriam colaborar para a solidificação dessa unidade, de acordo com a competência de cada esfera. A diferenciação das partes garantia a totalidade e, por sua vez, a unidade da sociedade portuguesa. Todos estavam subordinados uns aos outros. O rei dependia dos demais nobres. Estes, também estavam sujeitos aos oficiais mecânicos. Nesse sentido, subordinação dos grupos, uns para com os outros, era uma constante.

Não tratemos subordinação a partir de sinônimos contemporâneos, tais como submissão, obediência ou dominação. O pensar e, sobretudo, o agir nesse período eram manifestações de pessoas que não poderiam se identificar como portadoras de uma individualidade específica, manifestada pelo eu, categoria de caráter subjetivo e pertinente a cada sujeito existente.

A relação de sujeição entre os diferentes grupos sociais estabelecia-se para, precisamente, garantir a participação de todos, cada um atuando conforme sua competência. Pode soar estranha a ideia de ligação entre dependência e liberdade. Mas, para a maioria dos portugueses desse período, havia, sim, sentido na adoção dessa racionalidade.

O Cosmos, como obra do Criador, se predispunha a atuar definindo a ordem social presente na Terra. Ou seja, a disposição das diferentes partes existentes, dividindo-as hierarquicamente, refletia o estabelecimento do lugar de cada grupo social não somente na Terra, mas, sobretudo, nessa imensa totalidade maior.

Cada indivíduo era responsável por uma determinada atividade. O descumprimento de suas funções, no entendimento português, não prejudicaria somente a si próprio. Neste caso, a ausência de participação efetiva de um grupo em seu papel social acarretaria a desorganização de todo o quadro estabelecido.

A sincronia desse modelo de sociedade dependia justamente do cumprimento das funções desempenhadas por cada grupo. O ordenamento social estava ligado à manutenção das obrigações de cada um. Somente assim, por meio do estabelecimento dessa hierarquia, definindo a condição e função de todos, garantia-se o funcionamento considerado estável dessa sociedade.

Respeitando essa hierarquia, o rei era a figura de maior destaque. Cabia ao monarca à elevação do reino, aproximando-o sempre de Deus. O sucesso de 
Portugal em suas excursões para além-mar, na era dos Descobrimentos, seria não apenas o sucesso do reino. Como reino católico, Portugal atingia novas terras para a expansão dessa religião. Essa era uma das prerrogativas do rei. Garantir a manutenção da fé católica e expandi-la aos que a desconheciam.

A sociedade portuguesa, tal qual estamos traçando seus contornos, comparava-se a um corpo. A exemplificação do ordenamento social de então a partir de uma figura humana encontra suas bases no pensamento medieval. Como um grande corpo social, dividido entre cabeça e membros, organizavase o reino.

Cada grupo, assim como cada parte do corpo, possuía suas atribuições. O rei, como expoente máximo do catolicismo entre seus súditos era considerado a cabeça desse corpo. Os demais membros compunham, e, ao mesmo tempo, completavam essa disposição, conforme sua posição social.

Quando observamos o entendimento do mundo a partir da ideia de um Cosmos, interligando tudo e todos, conectando uns aos outros, percebemos a relação de interdependência presente no discurso que justificava esse modelo de ordenamento social. A realidade deveria ser explicada a partir dessa compreensão, pois os homens, naquele período, em sua maioria, sentiam-na e a vivenciavam dessa forma.

O mesmo processo se aplica ao buscar-se compreender a ideia de corpo social na dinâmica interna da sociedade portuguesa quinhentista. A origem medieval dessa concepção estende-se à modernidade, traduzindo a realidade de outra maneira.

Em conformidade com o restante desse corpo social, deveria agir o rei. Sua posição na sociedade não permitia opor-se aos demais membros, mas sim garantir o arranjo do processo de existência e funcionamento de toda a sociedade:
A função da cabeça (caput) não é, pois, a de destruir a autonomia de cada parte do corpo social (partium corporis operatio própria, o funcionamento próprio de cada uma das partes do corpo), mas por um lado, a de representar externamente a unidade do corpo, e, por outro, a de manter a harmonia entre todos os seus membros, atribuindo a cada um aquilo que lhe é próprio (ius suum cuique tribuendi). ${ }^{9}$

Devemos considerar o papel do rei perante o restante do corpo social também a partir da seguinte perspectiva: "as comunidades da Baixa Idade Média e dos tempos modernos foram de fato influenciadas pelo modelo eclesiástico, principalmente pelo protótipo espiritual onipresente dos conceitos corporativistas, o corpus mysticum da Igreja". ${ }^{10}$ Assumindo essa condição, as relações entre igreja e Estado produziram, ao longo da Idade Média e, subsequentemente, também na modernidade, uma ligação pautada por apropriações e trocas. 
Ao pensarmos na organização social portuguesa presente no século XVI necessitamos, antes de qualquer coisa, abandonar a concepção iluminista que ainda perpetua o pensamento moderno. A experiência social vivenciada na contemporaneidade faz-nos, por conta de sua historicidade, definir o curso da história como resultado das ações humanas, relegando a existência e providência divina a um segundo plano. Dessa forma, praticamente eliminamos essa mesma possibilidade do contexto das hipóteses para o entendimento do arranjo desse corpo social.

Organizada de forma diferente, "como um único corpo místico de vontades unificadas, a vontade coletiva subordinava-se no pactum subjectionis, que funda a hierarquia natural dos privilégios e a sacralidade da persona mystica ou ficta do rei" "11, fazendo, então, com que todo o reino, assim como seu soberano, obrigatoriamente se apresentasse como católico.

Sacralizado, o reino era composto de um só corpo social, em que os papéis de cada um dos membros dessa sociedade, cuja cabeça seria o Rei, organizavam-se de acordo com os preceitos hierárquicos estabelecidos pela fé. O reino era um grande corpo social e a figura do rei tinha de expressar todo sentimento de fé e unidade cristã existente no catolicismo português. Se assim o era, Hansen nos chama a atenção para a seguinte condição: "Assim como Cristo é, em sua humanidade, instrumentum divinitatis, como reza a Summa Theologica, também o rei é a figura, como persona ficta, da pessoa pública soberana em que se alienou o poder da comunidade". ${ }^{12}$

Essa forma de apreender a realidade fez com que os portugueses devessem passar a considerar a vida terrena de outra maneira, enxergando nela a possibilidade de um outro tipo de organização. A assimilação portuguesa do real conferia a todos o entendimento de que "é o Eterno que dá sentido próprio para a vida terrena figurada" ${ }_{13}$, regulamentando-a a partir de características muito peculiares.

Cabe ainda, ao analisarmos o papel do rei na sociedade portuguesa moderna, distinguir a duplicidade dos monarcas. Havia o homem, aquele que, como todos os demais, se estabelecia na condição de um ser mortal. Ao lado desse mesmo homem, se configurava outra identidade, própria somente do monarca. Os dois corpos do rei eram inseparáveis, contudo se diferenciaram conforme suas atribuições.

Observando o caso do Ducado de Lancaster, na Inglaterra seiscentista, quando da concessão de uma gleba de terra por parte do rei, enquanto menor de idade, podemos perceber essa diferenciação. O entendimento dos advogados da Coroa que analisaram o caso estabelecia o seguinte:

Pois o Rei tem em si dois Corpos, a saber, um Corpo natural e um Corpo político. Seu corpo natural (se considerado em si mesmo) é um corpo mortal, sujeito a todas as Enfermidades que ocorrem por Natureza ou Acidente, à Imbecilidade da 
Infância ou da Velhice e a Defeitos similares que ocorrem aos Corpos naturais de outras Pessoas. Mas seu corpo político é um Corpo que não pode ser visto ou tocado, composto de Política e Governo, e constituído para a Condução do Povo e a Administração do bem-estar público, e esse Corpo é extremamente vazio de Infância e Velhice e de outros Defeitos e Imbecilidades naturais, a que o Corpo natural está sujeito, e, devido a esta Causa, o que o Rei faz em seu Corpo político não pode ser invalidado ou frustrado por qualquer Incapacidade em seu Corpo natural. ${ }^{14}$

Um rei não se considerava capaz de celebrar o santo sacrifício da missa ou dispor-se a consagrar o pão e o vinho, na intenção de partilhar, entre os demais, o corpo de Cristo. Também não dispunha dos poderes dos exorcistas, que, segundo o entendimento medieval, eram capazes de identificar e expurgar a presença demoníaca entre os homens. ${ }^{15}$ Todas essas incumbências ficavam a cargo dos sacerdotes. Os clérigos exerciam tais funções, enquanto os leigos, mesmo no caso do monarca, não reivindicavam para si essas atribuições.

A posição do rei em meio à organização do corpo social o diferenciava dos demais homens, convertendo-os em súditos pelos poderes a ele investidos, expressos na condição de seu corpo político. Bloch salienta que não só os teóricos, mas toda a população, "sabia que para fazer um rei, e para fazê-lo taumaturgo, era necessário preencher duas condições [...] a 'consagração' e a 'linhagem direta"". ${ }^{16}$ Todos os monarcas possuíam plena certeza de sua posição frente esse processo. Mas há de se considerar o seguinte: o status legado ao rei, por sua posição junto ao corpo social, diferenciava-o dos outros homens, colocando-o em uma posição divergente dos demais.

A impossibilidade de agir em certos casos, em que os ritos exigiam a presença e execução das ações por parte de um clérigo, não lhe retirava a condição religiosa manifestada por meio do poder a ele investido. Confirmamos essa qualidade, considerando o seguinte: "Os reis sabiam muito bem que não eram de todo sacerdotes; mas eles também não se consideravam de todo leigos; em torno deles, muitos de seus súditos partilhavam desse sentimento". ${ }^{17}$ Mesmo não podendo ser considerado um sacerdote, seu cargo permitia um destaque distinto no eixo dessa sociedade.

Para além da figura do monarca, centrada no topo da sociedade corporativa, outras partes integravam o corpo social português. As diferenças existentes entre os integrantes da nobreza e os oficiais mecânicos servem para mostrar-nos o tipo de organização social que prevalecia no reino.

Uns - os nobres - viviam da administração de suas rendas e de seus ofícios, considerados de maior importância para o bom andamento do Estado. Outros - oficiais mecânicos - não eram considerados menos importantes, haja vista que todos integravam essa sociedade. Contudo, exerciam funções diversas das desempenhadas pela nobreza. 
No topo do grupo social tido como nobre surgiam os fidalgos. Fidalguia, pelo menos no início da idade moderna portuguesa, não se adquiria de qualquer maneira. Nascia-se fidalgo. Outra hipótese era ser elevado perante o rei. Tornava-se, por vontade régia, fidalgo. Com esse reconhecimento, surgiam honrarias e privilégios - todos culminantes com o ser nobre. Desencadeado por nascença ou prestígio real, pertencer à fidalguia significava consolidar-se junto à nobreza na sociedade corporativa. E essa materialização selava a posição social do fidalgo de nascença e de seus descendentes diretos e dos fidalgos da casa do rei. ${ }^{18}$

As formas de tratamento entre os integrantes da nobreza os distinguiam dos demais membros desse corpo social. Fidalgos deveriam ser apresentados não diretamente pelo primeiro nome. Antecedia-se a este a expressão Dom, utilizada para demarcar seu lugar na sociedade. Sentiam-se menos nobres os homens que não recebiam esse tipo de tratamento. Outras expressões atestam aquilo que a nobreza entendia ser falta de respeito. Dirigir-se diretamente a um nobre exigia conhecimento prévio de algumas regras: "No tratamento pronominal, um 'vós' podia resultar ofensivo, se o chamado se achava com direito a mais: 'vossa mercê', 'vossa senhoria' ou 'vossa excelência'". ${ }^{19}$

Pretendia-se, com isso, a constante referência a sua condição social, reconhecendo-a neste pequeno, mas significativo, gesto. O reconhecimento de suas virtudes ficava exposto às formas de tratamento. Sinais de sua adequação social a um determinado grupo, os nobres mantinham essa tradição.

Todo fidalgo era considerado nobre. Contudo, nem todo nobre poderia ser fidalgo. Na sociedade portuguesa existiam outras categorias que subdividiam a nobreza. Para além dos nobres de linhagem, sentiam-se nesse estado oficiais régios e negociantes abastados. Evidentemente que esse era o quadro português. ${ }^{20}$

\section{MUDANDO O CONTEXTO, RESSIGNIFICANDO O TEXTO: REPRESENTAÇÕES SIMBÓLICAS CORPORATIVAS NA AMÉRICA PORTUGUESA}

$\mathrm{Na}$ América, reproduzia-se esse modelo, consideradas algumas observações. A configuração dos estamentos na Colônia divergia da experiência social portuguesa. Por aqui eram necessários homens que administrassem os negócios ligados a terra, entre outras funções.

Delinear-se-ia outra realidade nos trópicos. Havia fidalgos, caso dos governadores gerais e de alguns oficiais da Coroa. Nas câmaras municipais os chamados homens bons se apresentavam junto ao restante da sociedade. Proprietários agrícolas também participavam desse processo. Alguns já eram considerados nobres no reino. Outros se elevariam ainda mais na América 
portuguesa, através da condução de seus negócios. Senhores de engenho, com efeito, enobreciam-se por intermédio da cana-de-açúcar aqui cultivada.

Condicionado, o ser nobre ligava-se a determinados elementos. Tornavam-se dignos dessa função aqueles que, bem nascidos, a herdavam ou, então, recebiam, por diferentes ocasiões, esse título de sua majestade. Virtudes, independentemente da maneira pela qual um homem se fazia nobre, eram indispensáveis para qualquer um nessa posição. Pautado pelo modelo corporativo, o Império português difundia essa concepção para além-mar.

As realidades desempenhadas entre essas duas terras eram tão distantes quanto à extensão do oceano que as guardavam. Porém, estamos a analisar uma sociedade que se firma na América com bases em uma vivência solidificada. O ser português na sociedade colonial luso-brasileira realizava-se a partir da reorganização de um arquétipo corporativo, resultado de uma forma mentis que não pode ser desprezada no ajustamento dessa experiência.

Moldava-se uma nova sociedade. Logo, com base na experiência cultural transposta para cá, as posições de cada um eram revistas, adequando-as às condições agora presentes.

Havia gente de toda sorte na Colônia. Mas, nem todos poderiam ser considerados nobres. Todos eram livres, nobres ou mecânicos, diferindo-se dos escravos, fossem estes indígenas ou africanos. O viver nobremente dava-se entre apenas alguns. Eram senhores de engenho, funcionários de sua majestade e os letrados que cá viviam. Dependendo de seus ofícios para sobreviverem, todos os demais constituíam a antítese dessa condição, completando esse quadro.

As atitudes de um nobre impediam-no de exercer qualquer tipo de ofício. Seu sustento deveria ser oriundo da administração de seus rendimentos ou de cargos públicos, designados pela Coroa. O trabalho, aquele que é acompanhado da necessidade produtiva de um serviço ou bem de consumo, era rejeitado pela nobreza. Constituída de uma genealogia que a deferia dos demais estamentos do corpo social português, ou tendo adquirido status no decorrer de sua vida, essa elite dispensava o labor, tido como pejorativo em seu meio social.

Interessava aos portugueses, além de uma descendência nobiliárquica, em que lugar se vivia e qual função era desempenhada pelo sujeito considerado nobre. Notemos o que diz Schwartz, ao tratar dessa questão, tecendo seus comentários acerca da sociedade baiana colonial:

Nobreza, na verdade, era uma questão de onde se vivia e o que se fazia, tanto quanto um título nobiliárquico. $\mathrm{Na}$ falta deste, senhores de engenho demonstravam seu status de nobreza levando uma vida senhorial, com uma grande propriedade fundiária, muitos escravos e agregados e a responsabilidade de prover a defesa da região. As primeiras doações de sesmarias na Bahia, que impuseram a condição de que os engenhos fornecessem armas e defesa, podem 
ser vistas como um reconhecimento da função militar dos senhores de engenho pioneiros. Para eles, isso era um símbolo de que sua posição na sociedade baiana era análoga à da nobreza em Portugal. A generosidade para com os seus iguais e dependentes, a autoridade sobre a família e os servidores, a hospitalidade e o senso de honra pessoal e familiar permitiam aos senhores de engenho agirem como nobres e, portanto, sê-lo. ${ }^{21}$

O jesuíta Fernão Cardim descreveu essa questão. Em 1583, o missionário conduzia o visitador Cristóvão Gouveia pela Bahia. Desejando visitar uma aldeia distante do local em que se encontravam, os jesuítas se viram obrigados a recorrerem ao socorro de um senhor de engenho que habitava aquela região. Mais tarde, Cardim narraria esse episódio da seguinte maneira:

Aquella noite nos agasalhou um homem rico, honrado, devoto da Companhia, em uma sua fazenda, com todas as aves e caças e outras muitas iguarias, e elle mesmo servia á mesa. Ao dia seguinte dissemos missa ante-manhã, a qual acabada já o almoço estava prestes de muitas e varias iguarias, que nos ajudaram passar aquelle dia muitos rios caudaes. $^{22}$

Outro exemplo interessante para podermos avaliar a divisão hierárquica na sociedade corporativa advém da ordenação nas procissões. Segundo Schwartz, "O protocolo e a precedência assumiam importante significado simbólico em eventos públicos e reforçavam a posição e as prerrogativas de cada grupo". ${ }^{23}$ Em outras palavras, como afirma Paiva: "A vida em conformidade com a fé era uma exigência cultural e, por isto, se fazia exigência pública, cabendo, pois aos governantes promovê-la e vigiá-la. O governante tinha que promovê-la e atalhar os desvios". ${ }^{24}$

Nas procissões, o corpo social português arranjava-se segundo uma disposição que colocava à frente toda a nobreza. Em segundo plano, surgiam os oficiais mecânicos. Mesmo especificamente no interior de cada grupo, havia uma subdivisão que reordenava a sequência dos participantes nas manifestações públicas de fé.

As procissões organizadas na cidade portuguesa de Loulé traziam consigo esta organização, atestando esta condição. Segundo um estabelecimento de 1564, primeiro seguia a nobreza, representada por fidalgos, cavaleiros e escudeiros. Na sequência, oficiais régios, caso dos tabeliãos e escrivãos. Atrás desses, apresentavam-se os mercadores. Mais a fundo, a procissão permitia avistar uma enormidade de oficiais mecânicos, também marcados por sua própria divisão: almocreves, carreiros, barbeiros, carpinteiros, pedreiros, sapateiros, ferradores, tosadores, abegões, alfaiates, ferreiros, alvanéis, 
albardeiros, serralheiros, oleiros, e, por fim, um conjunto de alpendoreiras padeiras, provisores, regatões e vendedeiras. ${ }^{25}$

Não é a toa que a distribuição das posições nas procissões fosse uma preocupação da sociedade portuguesa na modernidade. A forte divisão hierárquica estabelecida no Império português conduzia os lusitanos a essa realidade.

As manifestações públicas, conforme acabamos de demonstrar, apenas atestam essa condição. Como pudemos observar, todos, independentemente de sua origem, pertenciam ao corpo social, devendo, pois, obrigações ao monarca, ligados a ele que estavam pelo pacto de sujeição.

Mas essa ligação não abrangia tão somente ao rei. A cooperação mútua fazia-se indispensável para o funcionamento desse quadro social. Todos eram súditos, pois permaneciam submetidos ao rei. No entanto, os nobres, por serem mais próximos do monarca, de acordo com suas obrigações, possuíam lugar de destaque na sociedade. Distantes dessa circunstância, os oficiais mecânicos, como participantes da sociedade, podiam integrar-se às procissões. Porém, seus lugares eram, de antemão, demarcados.

Os funerais ocorridos sobre o óbice português também ilustram essa situação. Observando o tratamento decorrido da morte na sociedade baiana colonial podemos perceber esse fato. Aos membros da nobreza aplicava-se um enterro que pudesse corresponder a sua posição social. A morte para os mais abastados convertia-se em um espetáculo: "Um descendente de família nobre, um general famoso, ou um rico homem de negócios sabiam que seriam enterrados com toda pompa e circunstância". ${ }^{26}$

Fazia-se, entre os detentores de maior status social, questão da presença de religiosos e integrantes de irmandades. Assim sucedeu-se com Antonio Dias de Ottões, falecido no século XVII. Proprietário de vastas terras em Jucuruna, Bahia, este senhor de engenho havia, em 1653, organizado seu testamento. Nele, se pedia que todos os padres da Catedral e frades carmelitas acompanhassem seu enterro. Sendo irmão da Santa Casa de Misericórdia da Bahia, Ottões solicitava ainda a presença dos membros de todas as irmandades e ordens religiosas daquela cidade. Para tanto, os padres receberiam, cada um, uma vela e as irmandades uma contribuição em dinheiro ${ }^{27}$

Organizado o funeral e finalizado o enterro, a elite baiana não dispensava o cuidado com a morte apenas nestes dois itens. Era necessário encomendar quantas missas fosse possível. Após o falecimento, o rezar missa tornava-se condição essencial para a obtenção da salvação da alma. O número de missas variava, de acordo com a possibilidade financeira de cada um. O pedido era solicitado antes da morte, sendo que a quantidade pretendida ficava exposta nos cartas testamentárias.

Três tipos diferentes de missas eram realizadas. Primeiro, a de corpo presente. Em seguida, a de sétimo dia e, por último, uma quantia correspondente 
ao desejo do falecido. Havia, entre os irmãos maiores da Santa Casa baiana, homens que encomendavam até duas ou três missas diárias. Outros, como João de Mattos Aguiar, determinavam a celebração de onze mil missas por ano, na perspectiva de salvar não só sua alma, mas, também, a de seus pais e avós. Porém, estes casos constituíam uma exceção. ${ }^{28}$

Distante de toda essa realidade, os oficiais mecânicos não possuíam funerais de destaque, nem, tampouco, dispunham de recursos para garantir a solicitação de uma série de missas. A morte não trazia consigo uma valorização do indivíduo para os integrantes desse grupo. Se, ainda em vida, esses trabalhadores não adotassem as medidas necessárias, o seu destino final seria outro, inverso do exemplo que acabamos de mencionar:

As classes média e baixa já não receberiam reconhecimento póstumo semelhante. A menos que durante a vida houvessem tomado providências para o enterro, seus corpos seriam enterrados no 'campo do oleiro', cemitério reservado aos escravos e aos pobres. ${ }^{29}$

A hierarquia baseada na existência de estados, cada qual com seus direitos e obrigações, era regra rígida tanto no reino quanto na Colônia. O modelo corporativo de base teológica impunha esta condição a todos. A naturalização das funções e direitos de cada estamento conduzia à institucionalização - formal e legal, portanto jurídica - das prerrogativas de cada grupo:

Do ponto de vista social, o corporativismo promovia a imagem de uma sociedade rigorosamente hierarquizada, pois, numa sociedade naturalmente ordenada, a irredutibilidade das funções sociais conduz a irredutibilidade dos estatutos jurídico-institucionais (dos "estados", das ordens). ${ }^{30}$

Contudo, em terras brasílicas a realidade era outra. Os portugueses que por aqui desembarcaram não encontrariam uma sociedade historicamente marcada por esses traços. A adaptação da cultura vivenciada no reino exigia soluções diferentes das desempenhadas em Portugal. Como acabamos de destacar, a hierarquia dos estados era extremamente rígida na sociedade portuguesa. Mas, na América portuguesa, outras funções eram necessárias, enobrecendo indivíduos que, no reino, talvez não pudessem contar com um status diferenciado.

As grandes navegações e o desenvolvimento do comércio internacional traziam consigo a elevação da importância de diferentes funções. A nova dinâmica produz essa situação. Capitães de um conjunto de naus seriam elevados ao título de fidalgos da casa do rei, grandes mercadores, negociantes de escravos, passavam a atuar nos entrepostos comerciais, em especial na 
África. As novas terras anexadas exigiam a presença de oficiais régios e, no caso brasileiro, dos senhores de engenho. Todos se valiam dessa condição.

Alguns grupos considerados mecânicos na sociedade portuguesa e, portanto, também nos trópicos - caso dos artesãos - conseguiam furar este bloqueio. Organizados em torno de mestres e aprendizes, acumulando capital, lojas e empregados, estes trabalhadores chegaram a contar com representantes na câmara de Salvador. Infiltrados nas esferas de poder por intermédio do legislativo, os artesãos defendiam seus interesses perante o governo local. ${ }^{31}$

Ao finalizar e publicar no ano de 1576 seu Tratado da terra do Brasil, resultado de sua vivência nos trópicos entre 1565 e 1570, Pêro de Magalhães Gândavo incentivava os lisboetas e outros peninsulares a deixarem a Europa e aventurarem-se em terras desconhecidas. Descrevendo as capitanias brasílicas então existentes, este professor de latim que viveu na Bahia como funcionário da Coroa apresentaria uma imagem convidativa da Colônia. Era possível a qualquer português viver "honradamente na terra com mais descanço que neste Reino" 32 , podendo contar com o auxílio de índios para o preenchimento das provisões mais básicas, como pesca, caça e roças.

Outros tantos exemplos ilustram o ordenamento e a hierarquização da sociedade luso-colonial na América. Criadas a partir do final do século XV, no reinado de Dom Manuel I, as Irmandades das Santas Casas de Misericórdia portuguesas incorporavam esses elementos em sua composição. Com o objetivo de proporcionar assistência espiritual e material aos mais carentes, esta entidade, composta pelos chamados irmãos, era totalmente heterogênea. ${ }^{33}$

Nas Santas Casas os irmãos se dividiam em duas categorias - os maiores e os menores. Irmãos maiores eram os homens que despendiam de recursos financeiros extensos, enquanto irmãos menores seriam os oficiais mecânicos de todo tipo. A partir da segunda metade do século XVI criou-se a Santa Casa de Misericórdia da Bahia. A organização interna de sua irmandade denotava esse arranjo social. O organograma dessa entidade na América baseara-se no exemplo das Santas Casas existentes em Portugal.

Toda irmandade deveria possuir o seu conjunto de regras, denominado Compromisso. Sabemos que os baianos seguiam, desde pelo menos 1618, a regulamentação estabelecida pelo Compromisso da Santa Casa de Lisboa. Enquanto outras partes do Império português, como Goa e Macau possuíam seus próprios Compromissos, a Bahia optara por seguir as ordens estabelecidas no reino.

Lembremos-nos da metáfora utilizada pelos portugueses para estabelecer a divisão hierárquica que fundamentava a posição dos estados na sociedade. $\mathrm{O}$ reino, e por consequência todos que o integravam, era como um corpo. O rei seria a cabeça. Não era autônomo das demais partes, no entanto, deveria dirigir, com sabedoria, todas as demais funções corpóreas. O restante do corpo seria constituído pela nobreza, clero e oficiais mecânicos. Vital, com efeito, seria 
a participação de todos para o bom funcionamento da sociedade. $\mathrm{O}$ mesmo processo ocorria no cerne das Santas Casas.

O provedor, a exemplo do rei, era considerado a cabeça dessa instituição. Dirigente máximo da Santa Casa, ele jamais poderia ser um oficial mecânico. Nem qualquer nobre tornava-se responsável pela entidade. Fazia-se necessária experiência de vida, a qual os portugueses acreditavam poder ser obtida somente a partir da superação total da juventude. Todavia, não se obtinha tal cargo sem antes gozar de privilégios inerentes à nobreza.

Administrando uma Santa Casa, o provedor respondia diretamente por suas obrigações, tanto espirituais como materiais. $\mathrm{O}$ mais virtuoso dentre os integrantes da elite deveria ser encarregado desse papel. O Compromisso lisbonense de 1618 diz-nos da figura centrada na honra e sabedoria para ser elevada ao cargo de provedor. Este necessitaria, sem sombra de dúvidas, ser: “[...] homem fidalgo de authoridade, prudencia, virtude, reputação, e idade, de maneira, que os outros Irmãos o possão reconhecer por cabeça, e obedeção com mais facilidade [...] não poderá ser elleito de menos idade de quarenta annos". ${ }^{34}$

O mesmo Compromisso definia o número de participantes nas Irmandades. O documento aqui citado estabelecia o número de 600 irmãos, divididos igualitariamente entre nobres e oficiais mecânicos. Mas, assim como no episódio que acabamos de narrar, relativo ao provedor, os demais cargos de maior importância ficavam concentrados em mãos dos irmãos considerados maiores. Posições de extensa responsabilidade, a exemplo das funções de escrivão e tesoureiro, eram encargos atribuídos a senhores de engenho, criadores de gado, funcionários públicos, inquisidores, graduados em universidades e eclesiásticos na Bahia colonial. ${ }^{35}$

A divisão interna das Irmandades no Império português, pelo menos no caso luso-brasileiro, como observamos por intermédio da experiência baiana, expressava a autonomia de cada localidade. Mas, do seu núcleo de comando, grupo centrado na manutenção do poder, emergiam os senhores de engenho e outros integrantes da elite nordestina colonial. Aos demais irmãos - considerados menores por sua posição na sociedade - restava permanecer integrados às suas respectivas irmandades, colaborando conforme fosse necessário, de acordo com suas condições.

\section{CONSIDERAÇÕES FINAIS}

Desta forma, as irmandades seriam, sob uma perspectiva cultural, representações simbólicas do modelo corporativo português, resignificado pelo novo contexto desempenhado nestas terras. Não só as irmandades. As formas de tratamento no cumprimentarem-se, as procissões, os funerais, entre outros exemplos, tais como o rezar missa, os castigos aplicados e as demais funções 
desempenhadas nas diferentes dimensões do Império português, entre uma infinidade de tantas outras práticas, validavam traços de uma forma de ser que deveria se fazer presente em qualquer geografia.

Onde os portugueses desembarcassem, essa herança reinícola, centrada em bases corporativas de natureza teológica, disseminar-se-ia, em maior ou menor escala. Adaptando-se as novas realidades impostas pelos territórios e grupos desconhecidos, a forma de ser da gente da Península deveria ser estendida para além do Atlântico, conforme observamos nos casos citados em relação à América portuguesa.

Lemos novos textos, ressignificados pela diversidade do contexto divergente, ora experimentado com o processo de expansão das dimensões desse mesmo império. Dos contatos com os novos espaços até o estabelecimento do estar com o outro - pensando sempre nos diferentes atores envolvidos nesse processo, caso dos indígenas, negros, colonos brancos, padres da Companhia - vagarosamente o sentido do ser português, na sua estrutura social, iria moldarse conforme outra realidade.

Com efeito, suas transformações podem ser percebidas nas práticas da vida cotidiana, a luz de uma simbologia social dos gestos exercitados. Reaprendendo a ser, modificando sua forma, sempre com base na experiência anteriormente praticada, esses habitantes da Península conduziam sua (sobre) vivência na Colônia.

\section{NOTAS}

${ }^{1}$ HESPANHA, A. M.; XAVIER, Â. B.. A representação da sociedade e do poder. In: HESPANHA, A. M. (Org.). História de Portugal: o antigo regime (1620-1807). IV Vol. MATTOSO, José (Dir.). Lisboa: Estampa, 1993. p. 122. No que tange a expansão do Império português ao longo do Antigo Regime, as ideias apresentadas por Hespanha e Xavier corroboram para a compreensão da constituição do estado moderno luso-colonial. Todavia, cabe enfatizar o fato de que estes conceitos serão adaptados a uma nova realidade, pautada por outras experiências. Nesse sentido, observaremos o estabelecimento de práticas ligadas a um conjunto simbólico próprio da modernidade portuguesa, ancorado nas ideias de hierarquia, ordem e subordinação, articuladoras do universalismo inerente a cosmovisão portuguesa quinhentista.

2 HESPANHA, A. M.. História de Portugal moderno: político e institucional. Lisboa: Universidade Aberta, 1995. p. 29.

${ }^{3}$ HANSEN, J. A.. Ler \& ver: pressupostos da representação colonial, 1999. Disponível em: $<$ http://www.geocities.com/ail_br/lerverpressupostos.htm> Acesso em: 04 out. 2007.

${ }^{4}$ HESPANHA, A. M.; SILVA, A. C. N. A identidade portuguesa. In: HESPANHA, A. M. (Org.). História de Portugal: o antigo regime (1620-1807). IV Vol. MATTOSO, José (Dir.). Lisboa: Estampa, 1993. p. 20.

${ }^{5}$ Ibidem.

${ }^{6}$ MATTOSO, José. A escrita da história: teoria e métodos. Lisboa: Estampa, 1997. p. 130. 
7 Ibidem, p. 131.

8 Tratamos de uma sociedade com bases políticas alicerçadas nos moldes de uma antiga experiência (medieval) em associação com uma nova possibilidade (moderna), na qual elementos como mercancia e fé dispunham-se a associar-se ao processo de expansão marítima do Império português. Desenhamo-la tal qual a representação portuguesa quinhentista, isto é, como um corpo social. Composta pelo rei (cabeça) e demais súditos - nobres, clérigos, comerciantes, oficiais mecânicos, peões e escravos (membros superiores e inferiores), noções como hierarquia e ordem, advindas da organização cosmológica do mundo português, apresentam uma racionalidade política que se sustenta na figura do rei (representante da sacralidade de todo o reino), em associação com o restante de seu corpo social. Originário da ideia de corpo místico, herdada da Igreja católica, esse modelo de organização social se encontrava amparado no Direito, sendo, com efeito, amparado pelo Estado. A identidade portuguesa quinhentista, constituída pela posição dos diferentes indivíduos nesse desenho socialmente posto aos integrantes desse Império, deveria ser compartilhada a partir de um entendimento comum que visasse à colaboração das múltiplas partes com o todo, interligandoas pela presença da religiosidade a ser socializada pelos componentes deste mesmo reino. Esse era o entendimento existente, assentado em moldes corporativos, vivenciado pelos portugueses e legitimado, na forma da lei, pelo Estado. Nesse sentido, para uma visão específica do caso português, consultar HESPANHA e XAVIER, 1993. Considerando a interligação entre as ideias de corpo místico e corpo social, sugerimos a observação dos seguintes trabalhos: PÉCORA, A. Teatro do sacramento. A unidade teológico-retórico-política dos sermões de Antônio Vieira. São Paulo: Edusp, Campinas: Unicamp, 1994 e MURARO, V. F. Padre Antônio Vieira: retórica e utopia. Florianópolis: Insular, 2003. Para aferir os argumentos dados à sociedade portuguesa no decorrer do Antigo Regime, conferir o Sermão de Santo António aos peixes, pregado pelo jesuíta Antônio Vieira em 1654. A partir do conflito estabelecido com os colonos do Maranhão, em relação à escravização dos indígenas, Vieira explicita, alegoricamente, a ideia de corpo místico adotada pela Igreja e transposta para a configuração do Império português. Para tanto, sugerimos a seguinte edição: Sermões. Obras completas do Padre Antônio Vieira. ALVES, Gonçalo (Org.). Porto: Livraria Chardron, 1907-1909, 15 vols. Não tão conhecido quanto seu célebre homônio, o jesuíta brasileiro Antônio de Sá (1627-78), trata da relação entre corpo místico e corpo social, a partir de um sermão dedicado a ação de graças pelo restabelecimento do monarca adoentado. Nesse sentido, sua oratória estabelece relações entre a doença do corpo natural do rei e os agouros de seu corpo político, expresso por seu reino. Para tanto, consultar SÁ, Antônio. Sermões vários de padre Antonio de Saa da Companhia de Jesus oferecidos ao ilustríssimo e excelentíssimo senhor Marques de Marialva por Manoel da Conceição. Lisboa: Oficina de Miguel Rodrigues, Impressor do Excelentíssimo Senhor Patriarca, 1750.

${ }^{9}$ HESPANHA; XAVIER, op. cit., p. 123.

${ }^{10}$ KANTOROWICZ, E. H. Os dois corpos do rei: um estudo sobre teologia política medieval. São Paulo: Companhia das Letras, 1998. p. 126.

${ }^{11}$ HANSEN, J. A.. Prefácio. In: PÉCORA, A. Teatro do sacramento. A unidade teológicoretórico-política dos sermões de Antonio Vieira. São Paulo: Edusp; Campinas: Ed. Unicamp, 1994. p. 15.

${ }^{12}$ Ibidem, p. 16.

${ }^{13}$ Idem.

${ }^{14}$ Apud KANTOROWICZ, op. cit., p. 22.

${ }^{15}$ BLOCH, M. Os Reis Taumaturgos: o caráter sobrenatural do poder régio. França e Inglaterra.

2. Reimpressão. São Paulo: Companhia das Letras, 1999. 
${ }^{16}$ Ibidem, p. 169.

${ }^{17}$ Ibidem, p. 129.

${ }^{18}$ MAGALHÃES, J. R. A sociedade. In: . (Org.). História de Portugal: no alvorecer da Modernidade (1480-1620). III Vol. MATTOSO, J. (Dir.). Lisboa: Estampa, 1993.

${ }^{19}$ Ibidem, p. 489.

${ }^{20}$ Ibidem.

${ }^{21}$ SCHWARTZ, S. B. Segredos internos: engenhos e escravos na sociedade colonial 15501835. 2. Reimpressão. São Paulo: Companhia das Letras, 1999. p. 230.

${ }^{22}$ CARDIM, F. Tratados da terra e gente do Brasil. Belo Horizonte: Itatiaia; São Paulo: Edusp, 1980. p. 145.

${ }^{23}$ SCHWARTZ, op. cit., p. 210.

${ }^{24}$ PAIVA, J. M. Religiosidade e cultura brasileira - século XVI. In: PAIVA, J. M.; BITTAR, M.; ASSUNÇÃO, P. (Orgs.). Educação, história e cultura no Brasil colônia. São Paulo: Arké, 2007. p. 14.

${ }^{25}$ MAGALHÃES, op. cit.

${ }^{26}$ RUSSEL-WOOD, A. J. R. Fidalgos e filantrópicos: a Santa Casa de Misericórdia da Bahia, 1550-1755. Brasília: UNB, 1981, p. 153.

${ }^{27}$ Ibidem.

${ }^{28}$ Ibidem.

${ }^{29}$ Ibidem, p. 153.

${ }^{30}$ HESPANHA; XAVIER, op. cit., p. 130.

${ }^{31}$ RUSSEL-WOOD, op. cit., p. 153.

${ }^{32}$ GÂNDAVO, Pero de Magalhães. Tratado da província do Brasil. Rio de Janeiro: Itatiaia, 1980. Disponível em: <http://www.bibvirt.futuro.usp.br>. Acesso em: 04 out. 2007.

${ }^{33}$ RUSSEL-WOOD, op. cit., p. 153.

${ }^{34}$ Ibidem, p. 89.

${ }^{35}$ Ibidem.

Artigo recebido em novembro de 2011. Aceito em novembro de 2012. 